in the early years of its existence was largely due to Ross's influence and inspiration. Not only had he an extraordinary enthusiasm for the study of languages, but he was also capable of inspiring a like interest in others. $\mathrm{He}$ himself spoke a number of European as well as Oriental languages ; and it is a mark of his versatility that concurrently with his tenure of the chair of Persian he was also honorary lecturer in Portuguese at King's College, London. Nor was his interest that of the philologist only. His travels in Russia, Asia Minor, Central Asia, China and Persia had made his acquaintance with their tongues both intimate and colloquial. As was shown by much of his written work-he was an indefatigable and voluminous writer on an almost unlimited range of topics-a language was for him not so much an end of study in itself as an instrument for understanding the culture, the art, the institutions and the history of a people. This came out clearly in such of his written work as his study of the life and times of Omar Khayyám, or his introduction to Beckford's "Vathek", but can be most readily appreciated from his introduction to the catalogue of the exhibition of Persian art held at the Royal Academy in London, and in his contributions to the "Cambridge History of India". Apart from his studies and translations of works on Arabic, Persian and Indian history, literature, and art, one of his more noteworthy publications was a polyglot list of birds in Turki, Chinese, and Manchu.

Ross was a fellow of University College, London, and of the University of Calcutta. He was the recipient of academic honours from numerous universities, was knighted in 1918, and was awarded the Gold Medal of the Royal Asiatic Society in 1935. Early in the present year he was invited to become the head of the British Information Bureau at Istanbul, a position for which, as results showed, his personal gifts made him peculiarly well fitted in the present crisis in world affairs.

\section{Dr. J. Burtt-Davy}

Joseph BURtr-Davy, who died on August 20, was born on March 7, 1870, at Findern, Derby. He was educated privately. During 1891-92 he worked as an assistant in the Director's Office at Kew. On leaving Kew he went to California, where he worked as a research student and held various botanical posts in the University, finishing there in 1902 as instructor in botany. It was there that he also met his wife. Afterwards he served as assistant curator in the United States Department of Agriculture, Washington, D.C. During his stay in America he published several short papers on the vegetation of California, the vegetation and crops of the Colorado delta, and he contributed the accounts of the glumaceous families of Monocotyledons for Jepson's "Flora of Western Middle California".

In 1903, Burtt-Davy was appointed agrostologist and botanist in the Department of Agriculture at Pretoria, a post he held until 1913. During that time he made large collections of Transvaal plants which formed the basis for the fine national herbarium now housed at the Union Buildings, Pretoria. On leaving the Government service he started farming on his own account at Vereeniging in the Transvaal. He made this a success and retired soon after the War of 1914-18 in order to commence work on his "Flora of the Transvaal and Swaziland", settling at Kew for some years for this purpose. This entailed an immense amount of work, in which he was helped by various members of the Kew staff, whilst at times he employed two private assistants.

After publishing the first two parts of his Transvaal Flora, and preparing most of Part 3, however, Burtt-Davy gave up the work to take up the post of lecturer in tropical forest botany at the Imperial Forestry Institute, Oxford. There he helped to train many young forestry officers for departments overseas, who in return made herbarium collections for the forestry herbarium at Oxford. In this way Burtt-Davy brought together a most valuable herbarium of ligneous plants, which it will be necessary to consult for any floristic works that may happen to be written in the future.

Besides his floristic work, Burtt-Davy wrote many papers on various branches of botany. His largest and most important economic work was his book entitled "Maize, its History, Cultivation, Handling and Uses". He was particularly interested in ecology and wrote on the "Climate and Life Zones of the Transvaal", and on the "Suffrutescent Habit as an Adaptation to Environment". Burtt-Davy will be greatly missed by his many friends in forestry and botanical circles, and particularly at the annual meetings of the British Association, which he attended regularly.

J. Hutchinson.

\section{Miss E. L. Turner}

Miss Emma Louisa Turner, who died in Cambridge on August 13, was born in 1867. She was the pioneer of women bird photographers and was awarded the Gold Medal of the Royal Photographic Society. She was one of the first ten women fellows of the Linnean Society, and one of the first honorary lady members of the British Ornithologists' Union. She was also a president of the Norfolk and Norwich Naturalists' Society, vice-president of the Royal Society for the Protection of Birds and an honorary member of the Federation of University Women.

Though her early life was spent in Kent, Miss Turner will always be identified with Norfolk for her ornithological work there, both on the broads where, living in a houseboat at Hickling, she made an intensive study of marsh birds, and on Scolt Head where she spent much time alone as a voluntary watcher and made valuable records of bird migration.

Miss Turner had a gift for expression both in the spoken and written word and her lectures and books equally reflected her keen sense of humour. She was a valued supporter of the Cambridge Bird Club and her friendly readiness to assist with advice and encouragement gained for her the real affection of the undergraduates and the many friends with whom her bird work brought her in contact. P. B-S. 